\section{Eldre piloter, yrkessjåfører - og leger}

I Tidsskriftet nr. 2/2011 svarer Legeforeningens president (1) godt på gjentatte forespørsler angående foreningens syn på eldre leger og lisens, senest av Steinar Hagen i nr. 1/2011 (2).

Etter mitt syn bør

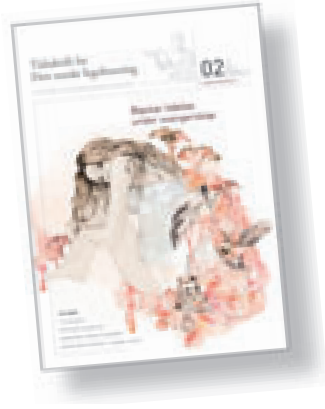

det av forsvarlighetshensyn være en øvre aldersgrense for legers lisens, slik det for eksempel er for piloter og for yrkessjåfører og bilførere generelt. Veitrafikkloven stopper yrkessjåfører når de er 75 år, deretter må de ha legeattest. Vanlige bilførere må ha helseattest etter fylte 70 år. Piloter og flygeledere stoppes når de er 65 år, uansett helsetilstand. Hva gjør leger annerledes enn disse?

Det vil være naturlig at vi leger mister lisensen når vi blir 75 år og at det bare unntaksvis gis forlengelse. Da bør det gjøres etter gitte kriterier og tester for å vurdere legens funksjonsevne. Det gjelder å kunne avdekke tilstander som demens, nevrologisk sykdom, symptomgivende kreft, psykiatrisk sykdom, synsforstyrrelser og annet som kan påvirke legens vurderingsevne.

\section{Lars Tjensvoll \\ Bærum \\ Litteratur \\ 1. Janbu T. Eldre leger og lisens. Tidsskr Nor Lege- foren 2011; 131: 111 \\ 2. Hagen S. Hvor er Legeforeningen? Tidsskr Nor Legeforen 2011; 131: 13-4.}

\section{Gradert treningsterapi kan ha skadelige effekter}

I Tidsskriftet nr. 3/2011 hevder Larun \& Malterud at individualisert gradert treningsterapi har positive helseeffekter ved kronisk utmattelsessyndrom og at forskning ikke gir støtte for at slik terapi er forbundet med bivirkninger, f.eks. i form av mer smerte (1).

Påstanden om at gradert treningsterapi er effektiv behandling ved kronisk utmattelsessyndrom er ikke holdbar. White og medarbeidere (2) fant i en nylig publisert studie at bare $28 \%$ av dem med «kronisk utmattelse» oppnådde gjennomsnittlig (median $\pm 1 \mathrm{SD}$ ) skår for utmattelse og fysisk funksjon etter gradert treningsterapi, sammenliknet med $15 \%$ av dem som fikk standard medisinsk behandling. Placeboeffekten for atferdsintervensjon er $14 \%$.

Den rapporterte bedring når det gjaldt utmattelse og fysisk funksjon lot seg imidlertid ikke bekrefte med signifikant objektiv bedring i fysisk aktivitet. Når man sammen- likner det eneste objektive målet - antall meter gått i løpet av seks minutter - kvalifiserer kognitiv terapi og gradert treningsterapi neppe engang som «moderat effektivt» (2).

Vårt syn er at anstrengelse har negativ innvirkning på mange pasienter (3). Dette kan forklares av at anstrengelse intensiverer preeksisterende biologiske patologiske tilstander: inflammasjon, nitrosativt/oksidativt stress, dysfunksjonelle smerteprosesser m.m. (3)

En nylig publisert studie viste at etter 12 måneder hadde ikke kognitiv terapi eller gradert treningsterapi bedret den helserelaterte livskvaliteten - tvert imot var skåren for fysisk funksjon redusert og skåren for kroppslig smerte økt (4). Resultatene underbygger ifølge forfatterne de «kontroversielle» funnene til Twisk \& Maes (3).

En oppfølging ett år etter av en av de sju (1) siterte studiene viste at $58 \%$ hadde fătt svekket fysisk funksjon av kognitiv terapi, gradert trening, anaerob trening eller terapeutisk avspenning (5). Pasientene viste tegn på immunaktivering og annen immunologisk anormalitet.

Vi mener derfor at det ikke er hold i Larun \& Malteruds tolking at videre forskning sannsynligvis vil støtte anbefalingen om tilpasset treningsbehandling. Tvert imot, det finnes sterke indikasjoner på at både kognitiv terapi og gradert treningsterapi har negativ effekt hos mange pasienter med kronisk utmattelsessyndrom.

\section{Frank N.M. Twisk}

Nederland

Michael Maes

Thailand

Lillian Festvåg

Nesodden

Litteratur

1. Larun L, Malterud K. Treningsbehandling ved kronisk utmattelsessyndrom. Tidsskr Nor Legeforen 2011; 131: 231-6.

2. White PD, Goldsmith KA, Johnson AL et al. Comparison of adaptive pacing therapy, cognitive behaviour therapy, graded exercise therapy, and specialist medical care for chronic fatigue syndrome (PACE): a randomised trial. Lancet 2011; 377: 823-36.

3. Twisk FN, Maes M. A review on cognitive behavorial therapy (CBT) and graded exercise therapy (GET) in myalgic encephalomyelitis (ME)/chronic fatigue syndrome (CFS): CBT/GET is not only ineffective and not evidence-based, but also potentially harmful for many patients with ME/CFS. Neuro Endocr Lett 2009; 30: 284-99.

4. Núñez M, Fernández-Solà J, Nuñez E et al. Health-related quality of life in patients with chronic fatigue syndrome: group cognitive behavioural therapy and graded exercise versus usual treatment. A randomised controlled trial with 1 year of follow-up. Clin Rheumatol 2011; 30: 381-9.

5. Jason LA, Torres-Harding S, Brown M et al. Predictors of change following participation in nonpharmacologic interventions for CFS. Tropical Medicine and Health 2008; 36: 23-32.

\section{Larun \& K. Malterud svarer:}

Vurdering av effekter og bivirkninger av fysisk aktivitet ved kronisk utmattelsessyndrom må bygge på systematisk kunnskap fra empiriske studier med adekvate utvalg og relevante utfallsmål. Vi har oppsummert effekten av treningsbehandling fra sju randomiserte, kontrollerte studier om utmattelse, smerte og helserelatert livskvalitet og finner positiv effekt på utmattelse, men usikre funn for smerte og helserelatert livskvalitet (1). En ny oversikt viser positiv effekt på utmattelse og selvrapportert fysisk funksjon (2).

Ingen av våre primærstudier rapporterer bivirkninger. I en annen studie om erfaringer med fysisk aktivitet rapporterte pasienter med kronisk utmattelsessyndrom at opplegget måtte være godt tilpasset og lystbetont, og de måtte selv ha styringen (3). Tilpasset treningsbehandling må ta utgangspunkt i den enkelte pasients behov fremfor et forhåndsdefinert treningsopplegg (www.cfstreningbehandling.no).

Twisk og medarbeidere refererer til primærstudier med motstridende resultater for effekt av treningsbehandling. Nunez og medarbeidere (4) brukte helserelatert livskvalitet som utfallsmål (kognitiv terapi og gradert treningsbehandling, $\mathrm{N}=60$ ), men fant ikke signifikante forskjeller etter 12 måneder. White og medarbeidere (5) brukte utmattelse og fysisk funksjon som primære utfallsmål (gradert treningsbehandling, $\mathrm{N}=$ $160)$, med positiv endring hos $41 \%$, mot $25 \%$ i kontrollgruppen $(\mathrm{p}=0,013)$. Studiene er ikke uten videre sammenliknbare, og systematiske oversikter gir bedre vitenskapelig tyngde enn funn fra enkeltstudier.

I en ny oversikt basert på individuelle pasientdata vil vi undersøke hva som er den «aktive ingrediensen» som gir positiv effekt, i håp om å forstå mer om hva som kan bidra til en bedre hverdag for pasienter med kronisk utmattelsessyndrom.

\section{Lillebeth Larun \\ Kirsti Malterud \\ Uni helse}

Litteratur

1. Larun L, Malterud K. Treningsbehandling ved kronisk utmattelsessyndrom. Tidsskr Nor Legeforen 2011; 131: $231-6$

2. Pinxterhuis I. Fysisk aktivitet som behandling ved myalgisk encefalopati. Ergoterapeuten 2011; 1: 1-9.

3. Larun L, Malterud K. Finding the right balance of physical activity. A focus group study about experiences among patients with chronic fatigue syndrome. Patient Educ Couns 2011; 83: 222-6.

4. Núñez M, Fernández-Solà J, Nuñez E et al. Health-related quality of life in patients with chronic fatigue syndrome: group cognitive behavioural therapy and graded exercise versus usual treatment. A randomised controlled trial with 1 year of follow-up. Clin Rheumatol 2011: 30: 381 -9.

5. White PD, Goldsmith KA, Johnson AL et al. Comparison of adaptive pacing therapy, cognitive behaviour therapy, graded exercise therapy, and specialist medical care for chronic fatigue syndrome (PACE): a randomised trial. Lancet 2011, 377: 823-36. 